\title{
THE ORMSKIRK POTATO RESEARCH STATION
}

\author{
By Dr. Redcliffe N. Salaman, F.R.S.
}

$\mathrm{F}^{\mathrm{R}}$ ROM the moment of its inception, the National Institute of Agricultural Botany included the potato as one of its major interests. However, before the Institute had time to formulate a constructive programme the Ministry of Agriculture handed to its care an orphan baby of doubtful parentage but intriguing personality, its wart trials at Ormskirk.

Since 1913, John Snell, a servant of the Ministry of Agriculture, had been conducting potato trials at Ormskirk on behalf of the Ministry, and in close co-operation with the local farmers who, alarmed by the rapid spread of wart disease in the northwestern counties, had of their own initiative taken steps to test existing and new varieties of potatoes for immunity to wart disease.

These trials were conducted in the highly infected kitchen garden of the Ormskirk Workhouse. In 1917, Sir Lawrence Weaver, controller of supplies in the Food Production Department, learnt of these trials and obtained Ministry support for an extension of their scope, which was urgently needed. In 1918, Miss Johnston, later Mrs. Snell, joined the staff as chief assistant and remained until 1920.

In 1920 the National Institute of Agricultural Botany, which had itself only come into being in January 1919 took over the wart trials, together with the staff, which was enlarged by the accession of Mr. H. Bryan, formerly horticultural inspector to the Ministry of Agriculture, and Miss Whitehead, later Mrs. McDermott.

In 1920, John Snell died and Mrs. Snell retired. Harold Bryan was appointed in his place; Miss Whitehead, who had been Snell's secretary, now became Bryan's chief assistant. These two officers have been responsible, under the Council, for all the work carried on at Ormskirk until this year, when the Ministry decided to close down the field wart tests. Throughout this entire period Mr. Sharrock, the farm foreman, ably seconded them in all their work.

With the susceptibility trials abolished, the National Institute of Agricultural Botany felt that the Station's raison d'être at Ormskirk had also ceased. It was realized that work to which the Council attached the highest importance, such as yield and maturity testing, and the selection of promising seedlings, which Ormskirk had made its own, could, in fact, be conducted to greater advantage in an uninfected area nearer to London and Cambridge. The break with Ormskirk, so far from marking the end of the National Institute's potato work, merely records the close of one stage, successfully accomplished, and the opening of another.

Mr. Bryan, who had been ailing for some time, died in August last, and Mrs. MeDermott has been temporarily seconded to the Midland Agricultural Station, where her expert knowledge of varieties will find further, and it is to be hoped an extended, usefulness.

Although the Ministry of Agriculture handed over to the National Institute of Agricultural Botany the task of controlling the testing for wart disease, the expenses of which it defrayed, it still retained the exclusive right of registering immune varieties which had been declared distinct by the Synonym Committee. The consequence has been that for twenty years co-operation between the Ministry and the Institute has been of the closest.

The primary work of the Ormskirk Station was to test all established varieties, both English and foreign, for their reaction to wart disease. At the same time opportunity was offered to breeders to send their seedlings to Ormskirk at an early stage so that their susceptibility might be ascertained and those subject to disease in the field eliminated.

The survey of existing varieties immediately brought to light a state of affairs the existence of which had scarcely been realized and the magnitude of which outstripped the wildest imagination. I allude to what has been called, perhaps somewhat clumsily, the problem of synonymity. The meaning of this term is, according to the Oxford English Dictionary, simple enough, namely, "the identity of nature of things having different names". Thus a variety the original name of which is, let us say, 'Golden Splendour', is, when first put on the market, identified by certain clearly recognized characteristics. Its maturity, skin colour, shape, depth of eye, and the like, together create a picture which lends it an identity of its own and ensures its recognition. We soon found that scores of socalled distinct varieties, bearing every sort of name other than "Golden Splendour", but yet identical with the authentic type, were being sold by seedsmen large and small, with but a few notable exceptions throughout the kingdom.

Snell initiated the battle of the synonyms, but died before the work had got thoroughly under way. The National Institute of Agricultural Botany now took over the task and appointed a 
committee of experts in 1919 to carry out the work, of which I have been chairman since its inception. The extent of the evil may be gauged by the fact that we found in existence some two hundred synonyms for the variety Up-to-date, and more than ninety each for Abundance and British Queen, whilst many seedsmen's catalogues recorded in glowing terms the superiority of the synonym to the mother stock, with which it had not infrequently shared the same sack in the store-house. In general, the synonym was priced at anything from 20 to 50 per cent or more higher than the original.

To-day the whole nexus of potato synonyms in Great Britain has, practically, been swept away. Much of the credit belongs to the Ormskirk staff; the fight was fierce at first, but such bitterness as there was, was sublimated in the form of newspaper articles and facetious poems addressed to me. Considering its magnitude and universality, the trade must be congratulated on the rapidity with which, when once its eyes were really opened, it rid itself of the evil. If the work at Ormskirk needed any justification, the abolition of potato synonyms alone would be enough, so far-reaching have been its repercussions throughout the whole of the horticultural and agricultural seed trade of Great Britain.

In order to determine the identity of the many hundreds of potato varieties which found their way to Ormskirk, it was necessary to build up as large a collection of existing varieties as possible, a task in which we were greatly assisted by the Scottish Board of Agriculture. This living museum, which contained some sorts which had been in cultivation more than a hundred years, will be preserved. It has been of great service in the training of inspectors to recognize "rogues" in the field.

The reaction to wart disease in the field of the great majority of existing varieties was tested during the first few years of the Station's existence, with the result that Ministry and farmer were henceforth in a position to know which varieties were fit to be grown in infected areas. At once it was evident that a veritable revolution in potato growing was inevitable; so many of the leading favourite varieties were susceptible and hence excluded. Ashleaf Kidney, Epicure, Duke of York, Sharpe's Express, Ninetyfold and Early Regent fell among the earlies, British Queen and Eclipse amongst the second earlies, Up-to-date, President, Magnum Bonum, Fortyfold, King Edward and Northern Star among the lates, to mention but a few of the most widely grown and best-known favourites of the first two decades of this century. Indeed, few really first-class varieties were left in any of the maturity groups.

The discovery of varieties immune to wart disease, first brought to light by Gough in 1908, provided at Ormskirk the basis of a new varietal selection whilst stimulating at the same time breeders in their efforts to fill the yawning gap in the choice of suitable sorts which the official exclusion of susceptible varieties had occasioned in the great wart potato-producing areas of Cheshire, Lancashire and the neighbouring counties.

Foremost among the breeders of new resistant varieties was, and still is, Mr. Donald MacKelvie, who, with others such as Mr. Watson of Messrs. McGill and Smith, Mr. Waight and the late Mr. Lasham of Messrs. Sutton and Sons, have consistently made the fullest use of the Station. Indeed, so great was the output of new seedlings, that it was soon found necessary to institute special seedling susceptibility trials to cope with them. At the same time Mr. J. W. Lesley and myself made use of the Institute's ground and experts, to test the susceptibility of seedlings raised at Barley, Herts, in the course of our research on the genetic inheritance of susceptibility and resistance to wart disease, the results of which were duly published, and gave further guidance to the breeders, many of whom were conversant with the new Mendelian principles.

From the first, Snell, with his magnetic personality, his wide experience and, not least, his gift of the 'winged word', created at Ormskirk an atmosphere hitherto unknown in the "potato world'. Members of the trade and growers from all parts of the United Kingdom in the autumn flocked to visit Ormskirk and hear Snell, and later Bryan, on whom Snell's mantle fell in rich measure, go round the plots, criticizing and appraising the old and the new. It was realized that with them no sort of interest other than that of the public good and the truth had any weight, and although reputations might be made and lost in one of these visits, during the whole twenty-one years of the Institute's activity there has never been a doubt raised in the mind of any as to the sincerity of the criticism offered, or the integrity of those who uttered them.

Prior to these early Ormskirk days, the potato had been regarded as a useful if rather dull article of food, any interest in which was, in the main, confined to the profits which might accrue in its exploitation. True, the monotony of normal trading might occasionally be broken by some financial boom, the most notorious of which occurred a few years before the Ormskirk activities began. On this occasion an inferior stock of an inferior variety was renamed Eldorado and sold for its weight in gold to a public only too ready to be beguiled. The excitement, the credulity, the folly and the fraud, together with the final dénouement resembled the South Sea Bubble in 
miniature. The advent of Snell and his successor Bryan, with their candid, not to say caustic, expression of the naked truth, put an end, it is to be hoped for good, to this kind of activity.

A number of circumstances combined to make the first ten years of the post-War period at Ormskirk notable. The stimulus to scientifically inspired breeding, which the presence of wart disease evoked, no less than the forceful personalities first of Snell and then of Bryan gave producer, trader and consumer, a confidence hitherto undreamt of. The genetic and virus research, which from the start found a welcome, induced an atmosphere of scientific and serious endeavour at the Station, whilst its close association with the Committee of Ormskirk Farmers ensured a due appreciation for the strictly practical exigencies of the producer, without which agricultural research in Great Britain need expect but short shrift. It is not too much to say that Ormskirk in these years became almost a place of pilgrimage, the Mecca of the potato-minded. Nor has it been supplanted in the esteem of its frequenters by any other centre. Until to-day, Ormskirk has remained the focal point of the varied interests concerned; what has happened is that those immediate interests have, so to speak, been saturated, and no fresh revolutionary force, with which Ormskirk might be fitted to deal, has arisen. How this saturation has been achieved must now be told.

Two memorials exist which epitomize two aspects of the work so far described, the strictly practical and the applied scientific: I refer to the Lord Derby and the Snell Memorial Medals. In 1915 Lord Derby gave a Gold Medal to be awarded annually by the Ormskirk Potato Society to the raiser of the potato variety best suited to local conditions. The trials took place on the Institute's ground and the merits of the varieties entered were adjudged by the Ormskirk Potato Society alone. In 1924 the Ormskirk farmers invited the National Institute of Agricultural Botany to cooperate with them. Since that time, the trials have become increasingly exacting, and the scope enlarged to include varieties suitable to all potatogrowing areas. In particular, the award is no longer based on superiority of yield alone, but much attention is paid to tolerance to virus infection and palatability. The medal has done much to encourage the production of new varieties. Experience has certainly not justified all the awards, whether made before or since 1924 . Indeed, it has been found desirable to extend the trials over a period of two years in order to reach a more reliable decision. In regard to both the potato and the medal, the adage that "All is not gold that glitters" has a special lesson, which it has taken many years of painful experience to acquire.
In 1921 the Council of the National Institute of Agricultural Botany decided to strike a Silver Medal to commemorate the pioneer work of John Snell. It was to be given to those who had done outstanding work whether as raiser, cultivator or scientific worker. The recognition of the latter's services is of interest because it covertly discloses the larger and more catholic attitude which the advent of the National Institute has brought about in this particular branch of horticultural endeavour.

In 1922, Spieckermann and Kotthof in Germany, and Miss Mary Glynne in England, developed the method of growing wart tissue in vitro with the view of developing controlled experiments on the infectivity of the wart organism and the susceptibility of potato varieties. These methods were further elaborated at Ormskirk in order to carry out rapid susceptibility tests for the convenience of breeders anxious to curtail the two years official field test which hitherto had been considered necessary. Mrs. McDermott devoted much time and attention to this work, and she and Bryan developed a most efficient and economic system of testing. The value of this work was greatly enhanced by the fact that parallel tests were carried out in every case in the field. This practice allowed of a very close comparison of the findings obtained by both methods. In addition they had the advantage of being able to refer specimens in cases of difficulty to Miss Glynne for histological examination. The work of the last twelve years in which every field test at Ormskirk has been duplicated in the glasshouse, has resulted in the complete calibration of glasshouse and field methods. Indeed, it is this very success of the indoor test as developed at Ormskirk which has been the main factor in inducing the Ministry to abandon the Station.

The testing for susceptibility to wart disease brought other advantages in its train: thus, it provided the opportunity of recording accurate descriptions of the botanical characters of the varieties examined, of which full advantage has been taken.

The activities so far described have all been either the direct, or indirect, results of the wart susceptibility trials, but there has been another and distinct line of research which the National Institute of Agricultural Botany has made its own. I refer to the accurate, statistically controlled, trials for the determination of yield and maturity of new and old potato varieties. The procedure underlying these trials was elaborated at Ormskirk and has become general wherever such trials are carried out. Each year several trials for yield or maturity or both, are carried out at Ormskirk and for many years they have been duplicated at Cambridge, Kirton, or elsewhere. In recent years 
the same trials have been repeated in a second year. The results from all these stations and of each year are carefully correlated. The twenty years of the Ormskirk trials, the results of which are to be found in the Institute's Journal, allow of a more or less complete comparison of the chief varieties in use to-day both as regards their yield and maturity.

The yield trials of first earlies have been further elaborated so as to estimate the relative capacity of individual varieties to bulk their tubers early. Such information is of considerable use to the producer who can, if he wishes, grow the variety which will render him the biggest crop at the moment when the markets are offering the highest prices.
Research on the control of eelworm under Prof. R. T. Leiper, of the London School of Tropical Medicine, has been pursued for many years at the Station; for this, however, the National Institute of Agricultural Botany has no official responsibility.

The Station at Ormskirk has a record rich in achievement to its credit; if its closure has brought a measure of disappointment to those who have served it so well, they would do well to take heart in the confident knowledge that the advantages which Ormskirk alone could offer have been exploited to the full, and that the lessons there learnt will assuredly bear even richer fruit when transplanted to another soil.

\section{THE SEARCH FOR TRUTH*}

\section{By Prof. H. S. Allen, F.R.S., UNIVERSITY OF ST. ANDREWS}

\section{TRUTH}

" 'WHAT is truth,' said jesting Pilate, and would not stay for an answer."

The word has, of course, acquired more specialized meanings, but the root idea is that there should be agreement between some statement or belief and some fact or set of facts.

It is consequently not surprising that science has been called the search for truth, but some qualification is desirable, for religion also may be regarded as the search for truth. The mere fact that we hear of the conflict between religion and science suggests that we are concerned with two different spheres of thought and activity.

\section{LoGIC}

Logic has been called the science of reasoning or 'the art of thinking'. It was Aristotle who first elaborated this method of examining the reasoning process, a method which is concerned not so much with matters of fact, the things reasoned about, as with the mental operations that are involved in 'thinking'. If, for example, we say, 'All professors are absent-minded', the pure logician has no occasion to decide whether this statement is in accordance with fact. $\mathrm{He}$ is concerned only with the abstract form of this proposition. It is because the hypotheses made by the logician are not necessarily in accordance with the facts of experience that many men of science feel sus-

- Based on an address to the Mathematical and Physical Society of the University of St. Andrews. picious of the results obtained by these methods of reasoning. Readers of Samuel Butler's allegorical and satirical book "Erewhon" will remember that "the Erewhonians were quick to offer up commensense at the shrine of logic".

Two methods of reasoning employed in logic are frequently mentioned in scientific work. They are 'deduction' and 'induction'. The former is described as the method in which reasoning proceeds from generals to particulars, and it is associated with the Greek philosophers who assumed that starting from certain 'innate' ideas it should be possible to deduce particular consequences. The term 'induction' implies reasoning from particulars to generals, that is to say the requisite materials of knowledge are brought to the mind and then analysed.

In these days, when the experimental method of scientific investigation has brought about such astounding revolutions in the life of man, there are very few who would assert that they adhere solely to the deductive process. Even on this oldtime 'conflict' a word of caution may be given. A somewhat cynical American physicist has said: "Facts are messy things, which everyone believes except the man who made the experiments; a theory is clear-cut and definite but no one believes it except the man who put it forward".

\section{The Spirit of Research}

The motive power of research-to paraphrase Prof. Whitehead-is a convietion that there is a secret, but "a secret which can be unveiled". Now 